\title{
Kelola
}

\section{EVALUASI PROGRAM SEKOLAH SEHAT DI SEKOLAH DASAR NEGERI}

\author{
Siti Zubaidah \\ Magister Manajemen Pendidikan \\ FKIP-Universitas Kristen Satya Wacana \\ sitizubaidah28031991@gmail.com \\ Bambang Ismanto \\ Magister Manajemen Pendidikan \\ FKIP-Universitas Kristen Satya Wacana \\ Bambang.ismanto@staff.uksw.edu \\ Bambang Suteng Sulasmono \\ Magister Manajemen Pendidikan \\ FKIP-Universitas Kristen Satya Wacana \\ sulasmonobambang@yahoo.com
}

\begin{abstract}
The aimed of this study was to evaluate the context, input, process, product of Healthy School program in Public School Kutowinangun 04 Salatiga (SD Negeri Kutowinangun 04 Salatiga). This study was evaluative research using CIPP model. The technique of collecting data using interviews, observation and documentation. Some of the steps being taken in the analysis of the data included: data collection, data reduction, data display and verification. Validation of data using triangulation techniques and resources. The results showed: (1) from the aspects of Context, the Healthy School program was the policy of the central government to improve the quality of education through the improvement of students health, in addition to the schools' needs, especially the students in Public School Kutowinangun 04 Salatiga were still low level of health, (2) from the aspect of Input, design program proved to be able to answer the need for the program to address the low level of students health, and supported by human resources, facilities and infrastructure, adequate cost, 3) from the aspect of Process, Healthy School Program has been run in accordance with program planned but on its implementation there were obstacles where schools have limited funds and inadequate infrastructure, and (4) from the aspect of Product, all targets to be achieved in program planned has been reached so that impacted the improvement of the quality of education in Public School Kutowinangun 04 Salatiga and therefore eligible to continue in the next period with several aspects improvements.
\end{abstract}

Keywords: Program Ecaluation, Healthy School, CIPP 


\section{PENDAHULUAN}

Pada era globalisasi ini banyak tantangan bagi peserta didik yang dapat mengancam kesehatan fisik dan jiwanya. Tidak sedikit anak yang menunjukkan perilaku tidak sehat, seperti lebih suka mengkonsumsi makanan tidak sehat yang tinggi lemak, gula, garam, rendah serat, meningkatkan resiko hipertensi, diabetes, obesitas dan sebagainya. Siswa sebelum makan tidak mencuci tangan terlebih dahulu, sehingga memungkinkan masuknya bibit penyakit kedalam tubuh. Hal ini mengacu pada pemikiran Hamiyah dan Jauhar (2015) bahwa perilaku tidak sehat ini juga disebabkan oleh lingkungan yang tidak sehat, seperti kurang bersihnya rumah, sekolah, atau lingkungan masyarakatnya.

Rendahnya upaya untuk menumbuhkan kesadaran hidup bersih dan sehat kepada peserta didik, berdampak pada siswa sekolah dasar yang belum sepenuhnya mengetahui bagaimana cara yang benar untuk memelihara kesehatan pribadi ataupun lingkungannya. Hal ini sejalan dengan hasil penelitian Teguh (2012) bahwa masih ada siswa yang menderita penyakit kulit, membiarkan rambut dan kuku memanjang tidak terawat, menderita gigi berlubang, kurang bersih dan rapi dalam berpakaian, kurang serius dalam melaksanakan senam setiap jumat pagi, sering membuang sampah sembarangan, jajan sembarangan dan tidak memperhatikan kebersihan jajanan. Hasil penelitian tersebut juga sejalan dengan penelitian Diana (2013:48) yang menunjukkan bahwa pelaksanaan program perilaku hidup bersih dan sehat yang masih rendah dapat berakibat pada kualitas lingkungan sekolah yang rendah dan masih tingginya angka penyakit yang menyerang anak usia sekolah.

Pemerintah mengeluarkan kebijakan sebagai upaya untuk meningkatkan kesehatan siswa dengan program "Sekolah Sehat". Sekolah Sehat adalah sekolah yang berhasil membantu peserta didik unggul secara optimal dengan mengedepankan aspek kesehatan. Sekolah Sehat selalu berusaha membangun kesehatan jasmani dan kesehatan rohani melalui pemahaman, kemampuan, dan perilaku yang bertanggung jawab, pengambilan keputusan terbaik untuk terciptanya kesehatan secara mandiri dapat diwujudkan (Arthur dan Barnard, 2011:4). Hasil penelitian diatas sejalan dengan penelitian yang dilakukan oleh Hermiyanti (2016:14) bahwa Sekolah Dasar Bersih Sehat (SDBS) adalah Sekolah Dasar yang warganya secara terus-menerus membudayakan PHBS, dan memiliki lingkungan sekolah yang bersih, indah, sejuk, segar, rapih, tertib, dan aman.

Menurut Panduan Pengembangan Model Sekolah Sehat di Indonesia (2009: 4), manfaat yang didapat dari program Sekolah Sehat antara lain: 1) bagi masyarakat yaitu sebagai tempat menghasilkan siswa yang mempunyai budaya hidup sehat dan aktif, 2) bagi pemerintah yaitu sebagai tempat pembelajaran yang dapat dijadikan percontohan bagi sekolah-sekolah lain karena diharapkan sekolah tersebut dapat menghasilkan sumber daya yang berkualitas, dan 3) bagi swasta atau dunia kerja yaitu dapat memberi peluang pada swasta untuk berperan dalam pengembangan Sekolah Sehat.

Kemendiknas Direktorat Jenderal Pendidikan Dasar (2009: 9) menjelaskan bahwa standar Sekolah Sehat meliputi: 1) Standar fisik sekolah yang meliputi: Bangunan sekolah yang memenuhi pembakuan standar minimal Depdiknas, sekolah memiliki akreditasi dari pemerintah, minimal B, sekolah yang memenuhi persyaratan kesehatan (fisik, mental, lingkungan), sekolah yang memiliki pagar, sekolah yang memiliki ruang terbuka yang memadai untuk pembelajaran pedidikan jasmani, dan sekolah memiliki sertifikat hak milik (SHM). 2) Standar sarana prasarana meliputi: memiliki sarana prasarana untuk pendidikan kesehatan yang memadai, memiliki sarana prasarana untuk pendidikan jasmani, 
memiliki sarana prasarana penunjang kegiatan UKS, 3) Standar ketenagaan yang meliputi: memiliki guru pendidikan jasmani, olahraga dan kesehatan, memiliki guru pembina UKS, memiliki kader kesehatan sekolah (dokter kecil, kader kesehatan remaja), 4) Standar peserta didik yang meliputi: memiliki derajat kesehatan yang optimal, tumbuh kembang secara optimal, dan memiliki tingkat kebugaran jasmani yang optimal.

Program Sekolah Sehat perlu disosialisasikan dan dilakukan dengan baik melalui pelayanan kesehatan yang didukung secara mantap dan memadai oleh sektor terkait lainnya, seperti partisipasi masyarakat, dunia usaha, dan media massa. Hal tersebut sesuai dengan pemikiran Hamiyah dan Jauhar (2015:267) yang menyatakan bahwa sekolah sebagai tempat berlangsungnya proses pembelajaran harus menjadi "Sekolah Sehat", yaitu sekolah yang dapat meningkatkan derajat kesehatan warga sekolahnya. Upaya ini dilakukan karena sekolah memiliki lingkungan kehidupan yang mencerminkan hidup sehat. Mengupayakan pelayanan kesehatan yang optimal, sehingga terjamin berlangsungnya proses pembelajaran dengan baik dan terciptanya kondisi yang mendukung tercapainya kemampuan peserta didik untuk berperilaku hidup sehat. Pendapat diatas sejalan dengan penelitian Irwandi (2016:492495) bahwa program sekolah berupa operasi semut, Sabtu bersih, upacara bendera, senam pagi, doa bersama, aubade dan UKS, merupakan kegiatan yang efektif untuk menumbuhkembangkan perilaku hidup sehat, yang melibatkan peran kepala sekolah, guru dan personil sekolah.

SD Negeri Kutowinangun 04 Salatiga merupakan salah satu Sekolah Dasar Negeri yang ada di kota Salatiga yang sudah menerapkan program Sekolah Sehat sejak tahun 2009. Berdasarkan wawancara dengan Kepala Sekolah, diketahui bahwa sejak awal dijalankannnya program Sekolah Sehat mulai tahun 2009 sampai tahun 2016 belum pernah dilakukan penelitian untuk mengevaluasi pelaksanaan program Sekolah Sehat di SD Negeri Kutowinangun 04 Salatiga. Maka dari itu, peneliti tertarik untuk melakukan evaluasi terhadap program Sekolah Sehat yang sudah berjalan sekitar 7 (tujuh) tahun. Arikunto dan Jabar (2014: 17) menyatakan bahwa evaluasi program adalah upaya untuk mengetahui efektivitas komponen program dalam mendukung pencapaian tujuan program. Tujuan evaluasi program adalah untuk menentukan apakah layanan atau intervensinya telah mencapai tujuan yang ditetapkan dan supaya dapat diketahui dengan pasti apakah pencapaian hasil, kemajuan dan hambatan yang dijumpai dalam pelaksanaan program dapat dinilai dan dipelajari untuk perbaikan pelaksanaan program dimasa yang akan mendatang (Wirawan: 2011).

Penelitian ini menggunakan model evaluasi CIPP yang dikembangkan oleh Stufflebeam pada tahun 1966. Menurut Arikunto \& Jabar (2014), apabila kegiatan evaluasi menggunakan model CIPP, analisis program harus berdasarkan pada komponenkomponen tersebut (CIPP), komponen dalam model evaluasi CIPP dapat dijelaskan sebagai berikut: 1) Evaluasi konteks berupaya mengidentifikasi mengenai kebutuhan lingkungan yang belum terpenuhi, populasi sampel yang dilayani dan tujuan program/proyek, 2) Evaluasi masukan berupaya mengidentifikasi tentang kemampuan awal dari komponen yang ada (siswa atau sekolah) dalam menunjang pelaksanaan program tersebut, 3) Evaluasi proses mengidentifikasi mengenai pelaksanaan dari suatu program yang dapat meliputi program apa yang akan dilaksanakan, siapa penyelenggara program tersebut, waktu pelaksanaan program tersebut, dan 4) Evaluasi produk berupaya untuk mengidentifikasi halhal atau perubahan yang terjadi dalam 
pelaksanaan program tersebut, serta ketercapaian dari pelaksanaan program.

Berdasarkan masalah diatas, penelitian ini akan mengevaluasi context, input, process, dan product program Sekolah Sehat di SD Negeri Kutowinangun 04 Salatiga. Tujuan penelitian ini adalah untuk memberi rekomendasi/masukan kepada SD $\mathrm{N}$ Kutowinangun $04 \quad$ Salatiga tentang pelaksanaan program Sekolah Sehat yang baik dan benar setelah mendapatkan hasil evaluasi context, input, process, dan product program sekolah sehat di SD Negeri Kutowinangun 04 Salatiga.

\section{METODE PENELITIAN}

Penelitian ini termasuk penelitian kualitatif evaluatif dengan model CIPP. Penelitian dilaksanakan di SD Negeri Kutowinangun 04 Salatiga dengan alamat Jalan Butuh 1-A RT 004/09 kota Salatiga. Sumber informasi meliputi: Kepala Sekolah, Guru, Koordinator Program Sekolah Sehat, Tenaga Pendidikan SD Negeri Kutowinangun 04 Salatiga. Data-data mengenai studi kelayakan, hasil analisis, SK penyelenggaraan, jadwal penyelenggaraan kegiatan, rencana program, piagam dan laporan penyelenggaraan program juga menjadi sumber data dalam penelitian. Teknik pengumpulan data yang digunakan dalam penelitian evaluasi program Sekolah Sehat di SD Negeri Kutowinangun 04 Salatiga adalah wawancara, observasi, dan studi dokumentasi. Beberapa tahapan yang dilakukan dalam analisis data dalam penelitian ini meliputi: (1) Pengumpulan data,

Reduksi Data, (3) Display Data, (4) Verifikasi/Kesimpulan data. Uji validitas data yang digunakan dalam penelitian ini menggunakan teknik triangulasi sumber dan triangulasi teknik.

\section{HASIL PENELITIAN DAN PEMBAHASAN}

\section{Hasil Penelitian}

Untuk mendapatkan data pada aspek context, input, process, dan product, peneliti melakukan wawancara terhadap Kepala Sekolah SD Negeri Kutowinangun 04 Salatiga, Ketua Program Sekolah Sehat, Guru Kelas, Tenaga Kependidikan serta melakukan studi dokumentasi dengan dokumen berupa Juknis Pengembangan Model Sekolah Sehat Tahun 2009, laporan penggunaan dana bantuan sekolah sehat, laporan kesehatan siswa, dokumen tentang data-data sekolah.

1. Evaluasi Context Program Sekolah Sehat di SD Negeri Kutowinangun 04 Salatiga

Pada tahap context, peneliti akan menganalisis tentang kebutuhan program, tujuan, manfaat dan peluang, serta sasaran program sekolah sehat di SD Negeri Kutowinangun 04 Salatiga. Berdasarkan hasil wawancara dan telaah dokumen, latar belakang dilaksanakannya program ini adalah penunjukan langsung oleh pemerintah pusat kepada SD Negeri Kutowinangun 04 Salatiga untuk menyelenggarakan program tersebut dikarenakan pihak pemerintah pusat memandang sekolah ini mampu dan layak baik dari segi SDM (Kepala Sekolah, Guru, Tenaga Kependidikan, Siswa, Komite), lingkungan maupun sarana prasarana dalam menunjang kelancaran penyelenggaraan program sekolah sehat disamping menjawab kebutuhan sekolah sebagai upaya peningkatan kesehatan siswa yang tergolong masih rendah. Tujuan pembentukan program Sekolah Sehat di SD Negeri Kutowinangun 04 Salatiga adalah untuk meningkatkan taraf kesehatan dan kebugaran jasmani para warga sekolah yaitu Siswa, Guru, Tenaga Kependidikan, Kepala Sekolah; agar memiliki sarana dan prasarana untuk pendidikan jasmani yang memadai serta menciptakan lingkungan sekolah yang bersih dan sehat yang mana hal tersebut juga akan berpengaruh terhadap proses belajar mengajar disekolah dan tujuan akhirnya adalah 
meningkatnya mutu pendidikan sekolah baik prestasi akademik maupun non akademik.

Manfaat yang diharapkan dari program Sekolah Sehat adalah meningkatnya tingkat kesehatan dan kebugaran jasmani siswa yang berdampak pada peningkatan kualitas pendidikan di sekolah, membuat lingkungan menjadi lebih bersih dan sehat dan membuat kondisi pembelajaran menjadi lebih nyaman dan prestasi sekolah meningkat, orang tua dan masyarakat lebih tenang menitipkan anak-anak mereka karena pola hidup sehat di sekolah akan terbawa dalam kehidupan di masyarakat, dan sekolah dapat menghasilkan sumber daya generasi penerus bangsa yang berkualitas. Sasaran program Sekolah Sehat yaitu Siswa, Guru, Tenaga Kependidikan, Kepala Sekolah, lingkungan, serta sarana dan prasarana.

2. Evaluasi Input Program Sekolah Sehat di SD Negeri Kutowinangun 04 Salatiga

SD Negeri Kutowinangun 04 Salatiga telah membuat perencanaan sebelum pelaksanaan program sekolah sehat. Didalam perencanaan tersebut terdapat beberapa bidang yang akan dikembangkan dalam program Sekolah Sehat yang meliputi 6 bidang yaitu: Pengembangan Program Pembelajaran, Pengembangan Sarana dan Prasarana, Pengembangan Ketenagaan, Pengembangan Manajemen Sekolah, Pengembangan Program Kemitraan, dan Pembiayaan. Selain berisi tentang beberapa macam kegiatan yang akan dijalankan, dalam perencanaan ini juga berisi tentang jadwal pelaksanaan, SDM yang bertanggung jawab dan terlibat, sarana prasarana dan biaya yang diperlukan untuk mendukung pelaksanaan setiap kegiatan dalam program sekolah sehat. Semua warga sekolah mulai dari kepala sekolah, guru, tenaga kependidikan, komite sekolah, siswa terlibat dalam perencanaan tersebut.

Dalam menjalankan program Sekolah Sehat, SD Negeri Kutowinangun 04 Salatiga menerima bantuan pembiayaan dari
Pemerintah Pusat melalui Direktorat Pusat Pengembangan Kualitas Jasmani-Depdiknas. Adapun jumlah bantuan yang diberikan adalah 67.600.000 (Enam puluh tujuh juta enam ratus ribu rupiah) yang diberikan pada tahun 2009 . Pada awal dijalankannya program sekolah sehat di SD Negeri Kutowinangun 04 Salatiga dana tersebut digunakan untuk melengkapi sarana prasarana (pembangunan fisik sekolah). Pada tahun-tahun berikutnya, pihak sekolah menggunakan dana BOS dan dana bantuan dari komite atau swasta dalam menjalankan program Sekolah Sehat khususnya yang berkaitan dengan bidang non fisik.

Mekanisme pelaksanaan program sekolah sehat yang dilaksanakan di SD Negeri Kutowinangun 04 Salatiga berpedoman pada juklak dan juknis dari pemerintah yang mana kepala sekolah, ketua program sekolah sehat dan guru yang sudah ditunjuk berperan sebagai penanggung jawab pelaksanaan program. Mekanisme penyaluran dana dari pusat ke sekolah juga sangat jelas mulai dari prosesnya, jumlahnya, dan penggunaan dana untuk program sekolah sehat sudah sesuai dengan prosedur dari pemerintah.

3. Evaluasi Process Program Sekolah Sehat di SD Negeri Kutowinangun 04 Salatiga

a. Pengembangan Program Pembelajaran

Pada aspek Pengembangan Program Pembelajaran, proses implementasinya sudah baik dari setiap indikator, dan dari tahun 2014 dan tahun 2015 mengalami peningkatan dalam pengembangan program pembelajaran. Kendala yang dihadapi sehingga belum bisa mencapai target $100 \%$ antara lain anggaran. Pada implementasi adanya peran aktif "pendidik sebaya" dalam PKHS juga belum mencapai $100 \%$ keberhasilan. Hal tersebut dikarenakan oleh pengetahuan dan kemampuan siswa dalam hal PKHS juga masih terbatas. Selain itu, banyak siswa yang tidak percaya diri apabila menjelaskan 
pengetahuan mereka tentang kesehatan kepada teman yang lain. Sedangkan pada aspek pelaporan penilaian kepada orang tua sudah berjalan sesuai target yang diinginkan. Kegiatan tersebut sudah mencapai keberhasilan $100 \%$ dilaksanakan oleh sekolah pada tahun 2014 dan 2015. Faktor yang mendukung atas kelancaran kegiatan tersebut tidak lepas dari peran serta semua warga sekolah mulai dari kepala sekolah, guru, tenaga kependidikan, komite sekolah, siswa dan juga orang tua siswa.

\section{b. Pengembangan Sarana dan Prasarana}

Pada subprogram sarana dan prasarana pendidikan kesehatan pihak sekolah belum memiliki ruang konseling yang khusus digunakan untuk membimbing dan memberi arahan kepada siswa yang membutuhkan. Belum adanya ruang konseling di SD Negeri Kutowinangun 04 Salatiga dikarenakan sekolah tidak mempunyai lahan yang cukup untuk dibangun kelas konseling dan juga selain lahan, sekolah juga terkendala dalam masalah dana untuk memperlancar proses pembangunannya. Pada implementasi pengembangan sarana prasarana UKS sebagian besar sudah berjalan dengan baik, sebagian besar peralatan UKS yang ideal sudah tersedia di UKS SD Negeri Kutowinangun 04 Salatiga. Pada implementasi pengembangan sarana prasarana pendidikan jasmani masih banyak indikator yang belum mencapai target $100 \%$ yaitu pada indikator ruang kelas memenuhi syarat kesehatan (ventilasi dan pencahayaan), memiliki lapangan terbuka dan atau aula, serta lapangan yang ada layak untuk PBM penjas. Hal tersebut dikarenakan pihak sekolah belum bisa merenovasi ruang kelas yang memenuhi syarat kesehatan seperti yang ada dalam peraturan.

c. Pengembangan Ketenagaan

Sebagian besar indikator dalam pengembangan ketenagaan sudah mencapai target, namun ada 2 indikator yang masih kurang dari target yaitu memiliki guru BP/BK dan juga memiliki guru Pembina UKS yang terlatih dengan jumlah yang memadai. Di SD Negeri Kutowinangun 04 Salatiga memang tidak ada guru yang khusus menjadi guru BP/BK untuk menangani masalah anak. Guru BP/BK dirangkap oleh Guru Kelas dibawah pengawasan dan bimbingan oleh kepala sekolah.

\section{d. Pengembangan Manajemen Sekolah}

Implementasi program pengembangan manajemen sekolah yang diarahkan pada pemenuhan desain kriteria Sekolah Sehat di SD Negeri Kutowinangun 04 Salatiga sudah dilaksanakan dengan baik. Dari 12 indikator dalam program pengembangan manajemen sekolah hanya ada 1 indikator yang masih jauh dari harapan yaitu adanya forum diskusi kelompok terarah dari pendidik sebaya/ konselor sebaya. Faktor yang menjadi kendala hal tersebut yaitu pendidik sebaya yang masih berusia anak-anak dan seharusnya dapat dijadikan contoh oleh teman yang lain masih memiliki mental yang kurang percaya diri untuk saling berdiskusi bertukar pendapat dengan teman yang lain. Hal tersebut membuat forum diskusi antar konselor sebaya menjadi tidak berjalan dengan baik.

\section{e. Pengembangan Program Kemitraan}

Hampir semua kegiatan sudah terlaksana dengan baik, terjadi peningkatan pada setiap indikator dari tahun 2014 ke tahun 2015 walaupun semua indikator belum mencapai $100 \%$ keberhasilan. Tetapi hal tersebut bertentangan dengan indikator adanya dukungan dari pemerintah daerah dan dewan. Indikator tersebut belum bisa terwujud dengan baik karena minimnya perhatian yang diberikan oleh Pemda dan DPRD terhadap program sekolah sehat. Kendala yang menghambat pengembangan kemitraan memang berasal dari waktu yang terbatas yang 
dimiliki oleh kepala sekolah dan guru yang seharusnya bertanggungjawab dalam menjalin kerjasama dengan mitra.

\section{f. Pengembangan Pembiayaan}

Implementasi program pengembangan pembiayaan program sekolah sehat di SD Negeri Kutowinangun 04 Salatiga sudah berjalan dengan baik. Hanya saja perhatian dari Pemerintah Daerah sangatlah minim, hal tersebut dibuktikan oleh tidak adanya dukungan dana dari APBD untuk program Sekolah Sehat. Sekolah menggunakan dana BOS dan dukungan dana dari pihak swasta dan orangtua siswa. Faktor pendukung pengembangan pembiayaan tersebut adalah adanya kesadaran yang besar dari orangtua siswa untuk mendukung setiap kegiatan program sekolah sehat. Selain itu kemampuan menjalin kerjasama dengan pihak swasta serta mengelola keuangan dana BOS oleh pihak sekolah juga sangat mempengaruhi pembiayaan sekolah sehat.

4. Evaluasi Product Program Sekolah Sehat di SD Negeri Kutowinangun 04 Salatiga

SD Negeri Kutowinangun 04 Salatiga telah mencapai tujuan dan target program Sekolah Sehat dengan baik. Tercapainya tujuan dan target awal dibuktikan dengan nilai tes kebugaran jasmani siswa per semester, meningkatkan pola hidup bersih dan sehat warga sekolah dibuktikan dengan prestasi siswa yang mengalami peningkatan 5\% per semester, meningkatkan sarana dan prasarana penjas yang sebelumnya hanya tersedia $50 \%$ meningkat menjadi $85 \%$, menciptakan lingkungan sekolah yang bersih dan nyaman untuk kegiatan belajar dibuktikan dengan dokumentasi lingkungan SD Negeri Kutowinangun 04 Salatiga.

Dampak yang telah dirasakan adalah kesehatan siswa dan warga sekolah lain menjadi lebih optimal ditunjukkan dengan nilai tes kebugaran jasmani siswa meningkat
5\% dari 65 menjadi 70 . Hal tersebut memicu konsentrasi siswa dalam melakukan aktifitas PBM maupun kegiatan di luar kelas. Apabila siswa fokus dan aktif dalam setiap kegiatan maka akan berdampak pada meningkatnya prestasi siswa baik akademik maupun non akademik yang telah ditunjukkan dengan meningkatnya prestasi siswa serta dapat meningkatkan mutu sekolah. Program Sekolah Sehat akan terus dilanjutkan di SD Negeri Kutowinangun 04 Salatiga untuk tahun-tahun berikutnya walaupun masih ada banyak perbaikan dalam implementasi kegiatan program.

\section{Pembahasan}

1. Evaluasi Context

Berdasarkan hasil penelitian yang peneliti lakukan, evaluasi context program Sekolah Sehat di SD Negeri Kutowinangun 04 Salatiga sudah sesuai dengan teori dan Juknis dari pemerintah. Selain merupakan kebijakan dari Pemerintah, program Sekolah Sehat juga dibutuhkan oleh sekolah mengingat tingkat kesehatan siswa yang sangat rendah. Tujuan dan manfaat program Sekolah Sehat juga sangat dirasakan dalam membantu sekolah mencapai kualitas pendidikan yang optimal. Sasaran program sekolah sehat sudah sesuai dengan teori dan Juknis bahwa siswa merupakan sasaran utama yang harus diperhatikan dalam penyelenggaraan program Sekolah Sehat. Hasil penelitian tersebut sejalan dengan penelitian yang pernah dilakukan oleh Sari (2013) bahwa tujuan dari pendidikan kesehatan adalah mengubah perilaku yang tidak sehat menjadi sehat baik pada individu, kelompok, dan masyarakat. Siswa sebagai subjek dalam pembelajaran pendidikan kesehatan diharapkan mampu menerapkan hidup sehat dalam kehidupan sehari-hari.

\section{Evaluasi Input}


Program Sekolah Sehat di SD Negeri Kutowinangun 04 Salatiga dilihat dari segi input sudah menjawab kebutuhan program yang terdiri dari 6 bidang pengembangan yaitu (1) Pengembangan Program Pembelajaran, (2) Pengembangan Sarana dan Prasarana, (3) Pengembangan Ketenagaan,

Pengembangan Manajemen Sekolah, (5) Pengembangan Program Kemitraan, (6) Pengembangan Pembiayaan. Masing-masing bidang pengembangan terdiri atas beberapa subprogram dan indikator kegiatan yang disusun sesuai dengan Juknis yang ditentukan pemerintah dan dilengkapi dengan SDM, sarana dan prasarana serta dana yang memadai. Hasil penelitian diatas sejalan dengan penelitian Ahmad (2013) yang menyatakan bahwa keberhasilan pencapaian suatu program dipengaruhi oleh ketersediaan dana. Sejalan dengan penelitian tersebut, hasil penelitian Handayani (2008) juga menyatakan bahwa fasilitas/sarana prasarana diposisikan sebagai faktor pendukung untuk keberhasilan suatu program.

\section{Evaluasi Process}

\section{a. Pengembangan Program Pembelajaran}

Pengembangan program pembelajaran di SD Negeri Kutowinangun 04 Salatiga sudah berjalan dengan baik yaitu tercapai lebih dari $80 \%$. Pihak sekolah telah berusaha untuk memaksimalkan pengembangan program pembelajaran, karena mereka sadar dengan program pembelajaran yang berkualitas maka juga akan tercipta SDM yang berkualitas. Hal tersebut sejalan dengan pendapat Abdul Majid (2006) yang mengatakan bahwa pengembangan pembelajaran perlu dikelola dengan baik agar dapat mencapai hasil yang optimal. Untuk mewujudkan hal tersebut, pengelolaan pembelajaran merupakan kunci keberhasilan menuju pembelajaran yang berkualitas.

b. Pengembangan Sarana dan Prasarana
Pengembangan sarana prasarana pendidikan kesehatan pada program Sekolah Sehat di SD Negeri Kutowinangun 04 Salatiga telah dilaksanakan dengan baik, dari 11 indikator terdapat 10 indikator yang pencapaiannya sudah $100 \%$. Sarana prasarana yang lengkap akan berdampak pada mutu pendidikan di sekolah tersebut. Hasil penelitian ini sesuai dengan penelitian yang dilakukan oleh Setyorini (2009) yang menemukan bahwa Sarana dan prasarana yang baik sangat membantu keberhasilan mutu pendidikan. Semakin lengkap dan dimanfaatkan secara optimal, sarana dan prasarana suatu sekolah tentu semakin mempermudah murid dan guru untuk mencapai target secara bersama-sama.

\section{c. Pengembangan Ketenagakerjaan}

Pengembangan ketenagaan di SD Negeri Kutowinangun 04 Salatiga sudah cukup baik. Sekolah sudah memiliki tenaga pengajar pendidikan jasmani yang memenuhi kualifikasi. Sejalan dengan Undang-Undang Nomor 14 Tahun 2005 yang mengatakan bahwa guru adalah tenaga pendidik yang profesional yang bertugas mendidik, mengajar, melatih, membimbing, dan mengevaluasi peserta didik. Guru adalah tenaga pendidik yang berpengalaman dalam bidang profesinya yang memberikan sejumlah ilmu pengetahuan kepada siswanya di sekolah. Dengan ilmu yang dimilikinya, guru dapat menjadikan siswanya menjadi cerdas dan memiliki pribadi yang baik.

\section{d. Pengembangan Manajemen Sekolah}

Pengembangan manajemen sekolah berbasis pemenuhan kebutuhan kriteria desain sekolah sehat di SD Negeri Kutowinangun 04 Salatiga sudah berjalan dengan baik. Kerjasama dan tanggung jawab yang tinggi dari semua warga sekolah merupakan kunci utama suksesnya manajemen sekolah. Hasil tersebut sejalan dengan pendapat Danim 
(2012) yang mengatakan bahwa salah satu faktor pendukung peningkatan mutu pendidikan di sekolah adalah Jaringan Kerjasama, dimana jaringan kerjasama tidak hanya terbatas pada lingkungan sekolah dan masyarakat semata (orang tua dan masyarakat) tetapi dengan organisasi lain, seperti perusahaan / instansi sehingga output dari sekolah dapat terserap didalam dunia kerja.

\section{e. Pengembangan Program Kemitraan}

Pengembangan program kemitraan di SD Negeri Kutowinangun 04 Salatiga berjalan cukup baik, hanya saja dukungan dari pemerintah daerah dan dewan untuk program Sekolah Sehat masih sangat rendah. Rendahnya dukungan dari pemerintah daerah bertolak belakang dengan pendapat Dwiyanto (2005) yang mengatakan bahwa Pemerintah Daerah seharusnya memiliki kebijakan untuk memberikan pelayanan kepada masyarakat atau institusi pendidikan terkait dengan program-program yang ada dan dijalankan oleh masyarakat atau lembaga terkait.

\section{f. Pengembangan Pembiayaan}

Pengembangan pembiayaan program sekolah sehat di SD Negeri Kutowinangun 04 Salatiga sudah berjalan dengan baik. Dana progam sekolah sehat berasal dari Pemerintah Pusat dan bantuan dari orangtua siswa. Kepala dan Bendahara Sekolah harus pandai dalam mengalokasikan sebagian dana BOS untuk digunakan dalam implementasi program Sekolah Sehat. Hal tersebut sejalan dengan pendapat Fattah (2009) mengatakan bahwa jika tidak memungkinkan menggantungkan sepenuhnya pada subsidi pemerintah diperlukan kemampuan dalam menyerap dana masyarakat, akan tetapi jangan sampai membebani peserta didik dari latar belakang keluarga yang kurang mampu.

\section{Evaluasi Product}

SD Negeri Kutowinangun 04 Salatiga telah mencapai tujuan dan target program Sekolah Sehat dengan baik. Dampak yang telah dirasakan adalah kesehatan siswa dan warga sekolah lain menjadi lebih optimal sehingga dapat meningkatkan prestasi siswa baik akademik maupun non akademik. Kesehatan merupakan salah satu faktor penentu keberhasilan belajar siswa, sejalan dengan pendapat Kartono Kartini dalam Tulus Tu'u (2004) bahwa faktor-faktor yang menghambat prestasi belajar siswa antara lain penghambat dari dalam dan penghambat dari luar. Penghambat dari dalam meliputi salah satunya adalah faktor kesehatan. Siswa yang kesehatannya sering terganggu menyebabkan anak tertinggal pelajarannya, oleh karena itu orang tua dan sekolah harus memperhatikan kesehatan anak-anaknya dengan makanan yang bergizi dan pola hidup sehat, begitu juga sebaliknya apabila kesehatan siswa optimal maka anak akan maksimal dalam pelajarannya. Program Sekolah Sehat akan terus dilanjutkan di SD Negeri Kutowinangun 04 Salatiga untuk tahun-tahun berikutnya walaupun masih ada banyak perbaikan dalam implementasi kegiatan program.

\section{SIMPULAN DAN SARAN}

\section{Simpulan}

Hasil evaluasi di atas menunjukkan bahwa, pada evaluasi context, program Sekolah Sehat di SD Negeri Kutowinangun 04 Salatiga memang dibutuhkan oleh stakeholder sekolah yang sekaligus merupakan kebijakan dari Pemerintah Pusat. Dari segi input, Program Sekolah Sehat di SD Negeri Kutowinangun 04 Salatiga yang terdiri dari 6 bidang pengembangan sudah menjawab kebutuhan sekolah. Selain itu program juga disusun sesuai dengan Juknis yang ditentukan pemerintah dan dilengkapi dengan SDM, sarana dan prasarana serta dana yang memadai. Penyelenggaraan program Sekolah Sehat di SD Negeri Kutowinangun 04 Salatiga 
dari segi process telah dilaksanakan sesuai dengan perencanaan program walaupun masih ditemui kendala dalam pelaksanaannya yaitu keterbatasan biaya dan sarana prasarana. Dari segi Product Program Sekolah Sehat di SD Negeri Kutowinangun 04 Salatiga telah mencapai sebagian besar dari hasil yang direncanakan. Hasil-hasil tersebut adalah a) pembangunan fisik sekolah menjadi lebih baik dan lengkap, b) bidang non fisik meliputi peningkatan kesehatan dan kebugaran jasmani warga sekolah, pola hidup bersih dan sehat warga sekolah, lingkungan sekolah menjadi lebih bersih dan nyaman untuk belajar sehingga akan berdampak pada peningkatan prestasi siswa baik akademik maupun non akademik serta peningkatan mutu sekolah. Program Sekolah Sehat di SD Negeri Kutowinangun 04 Salatiga akan tetap dilanjutkan pada tahun-tahun berikutnya mengingat banyak manfaat yang positif baik untuk siswa maupun sekolah.

\section{Saran}

Terdapat beberapa saran yang peneliti sampaikan guna perbaikan penyelenggaraan program Sekolah Sehat pada periode berikutnya, yaitu:

1. Bagi sekolah

a. Sekolah harus lebih intensif dalam menjalin kerjasama dengan pihak lain (swasta, komite, orangtua, APBD) dan yang terkait dengan program sekolah sehat lainnya untuk mendapatkan bantuan dana dalam mendukung pelaksanaan program.

b. Sekolah harus melengkapi sarana dan prasarana yang belum dimiliki yaitu ruang $\mathrm{BP} / \mathrm{BK}$, ruangan aula, ruang khusus untuk pengumpulan hasil bank sampah dan juga tempat untuk pembuatan pupuk kompos.

2. Bagi Dinas Pendidikan
Dinas perlu melakukan monitoring dan evaluasi terhadap penyelenggaraan program sekolah sehat di sekolah-sekolah penyelenggara program sekolah sehat, khususnya di SD Negeri Kutowinangun 04 Salatiga. Dengan demikian, Dinas Pendidikan dapat mengambil kebijakan berupa perbaikan atau penyempurnaan proses penyelenggaraan program Sekolah Sehat di masa datang.

3. Bagi Instansi pemberi dana (Direktorat Pusat Pengembangan Kualitas Jasmani)

Program Sekolah Sehat sebaiknya tetap dilanjutkan dengan penyempurnaan serta dukungan dana mengingat banyak manfaat yang diperoleh dari program ini.

\section{DAFTAR PUSTAKA}

Abdul, Majid. 2006. Perencanaan Pembelajaran. Bandung: PT Remaja Rosdakarya

Ahmad, Asiah Hamzah dan Ida Leida Maria. 2013. Pelaksanaan Program Jaminan Persalinan (Jampersal) Di Dinas Kesehatan Kabupaten Buol. Jurnal $A K K$, Vol. 2, No 2.Mei, hal: 19-28

Arikunto, Suharsimi dan Cepi Safrudin Abdul Jabar. 2014. Evaluasi Program Pendidikan. Jakarta: Bumi Aksara

Arthur Sue, Matt Barnard, DKK. 2011. Evaluation of National Healthy Schools Programme. Department of Health

Danim, Sudarwan. (2012). Inovasi Pendidikan

Dalam Upaya Peningkatan

Profesionalisme Tenaga Kependidikan. Bandung: Pustaka Setia

Diana, Fivi Melva, dkk. 2013. Pelaksanaan Program Perilaku Hidup Bersih dan Sehat (PHBS) Di SD Negeri 001 Tanjung Balai Karimun. Jurnal Kesehatan Masyarakat. Vol.8, No.1, September, hal: 46-51 
Dwiyanto, Agus. 2005. Mewujudkan Good Governance Melalui Pelayanan Publik. Yogyakarta: Gajah Mada University Press.

Fattah, Nanang. (2009). Ekonomi dan Pembiayaan Pendidikan. Bandung: Remaja Rosdakarya

Hamiyah, Nur dan Jauhar. 2015. Pengantar Manajemen Pendidikan Di Sekolah. Jakarta: Prestasi Pustakaraya

Handayani, Lina. 2008. Evaluasi Program Pemberian Makanan Tambahan Anak Balita. FKM Universitas Ahmad Dahlan, Yogyakarta

Hermiyanty, Lusia Salmawati, Fandi Oktavian. 2016. Evaluasi Implementasi Program Sekolah Dasar Bersih dan Sehat Di Kota Palu.

Irwandi, Satria. 2016. Peran Sekolah Dalam Menumbuhkembangkan Perilaku Hidup Sehat Pada Siswa Sekolah Dasar (Studi Multi Situs Di SD Negeri 6 Mataram dan SD Negeri 41 Mataram Kota Mataram Nusa Tenggara Barat). Malang: Manajemen Pendidikan Pascasarjana-Universitas Negeri Malang.

Kemendiknas Direktorat Jenderal Pendidikan Dasar Tahun 2009 Tentang Panduan Pengembangan Model Sekolah Sehat di Indonesia

Sari, Indah Prasetyawati. 2013. Pendidikan Kesehatan Sekolah Sebagai Proses Perubahan Perilaku Siswa. Jurnal Pendidikan Jasmani Indonesia. Volume 9, No 2, November, hal: 141147

Setyorini dkk. 2009. Masalah Pendidikan di Indonesia. Solo: Universitas Negeri Sebelas Maret.
Sudijono, Anas. 2006. Pengantar Evaluasi Pendidikan. Jakarta: Radja Grafindo Persada.

Teguh A. 2012. Survei Pelaksanaan UKS dan Pola Hidup Sehat Siswa SD Kelas V se-Gusek Bramasari, Kecamatan Leksono, Kabupaten Wonosobo Tahun 2012. UNY

Tulus, Tu'u. 2004. Peran Disiplin Pada Perilaku dan Prestasi Siswa. Jakarta : PT. Gramedia Widia Sarana Indonesia.

Undang-Undang Nomor 14 Tahun 2005 Tentang Guru dan Dosen

Wirawan. 2011. Evaluasi (Teori, Model, Standar, Aplikasi, dan Profesi). Jakarta: Rajagrafindo Persada. 